\title{
GERAKAN ANTI-KOLONIALISME MENUJU INDONESIA MERDEKA DALAM PERSPEKTIF SMELSERIAN
}

\author{
Yudhi Rachman
}

Program Studi Sosiologi, FISIB, Universitas Trunojoyo Madura

kak_yodee@yahoo.com

\begin{abstract}
This paper aims to provide an overview of Indonesia's social, political and economic conditions at the beginning of the 20th century. Changes in the movement of history are marked by the emergence of political resistance and revolutionary movements, including the establishment of the Islamic nationalist movement represented by the Sarekat Islam, the radical nationalist movement represented by Indische Partij and Insulinde, and the Marxist Communist Party of the Dutch East Indies. This study uses a library study method to explain the constellation of the movement of anti-colonialism in the Smelserian perspective. This research shows that social movements in Indonesia at the beginning of the 20th century arose due to dissatisfaction with existing social structures. Indisce Partij, for example, dared to declare itself a political party for all ethnic groups in Indonesia and collaborated with Sarikat Islam which was a large Islamic organization at that time. Likewise with the emergence of the communist movement which was initially brought in by a handful of Dutch people, it began to dare to voice its demands more radically in opposing Dutch imperialism and capitalism in Indonesia. This is the embryos of political resistance which color the constellation of the history of the Indonesian people towards their ideals of independence.
\end{abstract}

Keywords: nationalism, mass organizations, social movement, Smelser

\begin{abstract}
Abstrak
Tulisan ini bertujuan memberikan gambaran kondisi sosial, politik dan ekonomi Indonesia pada awal abad ke-20. Perubahan gerak sejarah ditandai dengan munculnya perlawanan politik dan gerakan revolusioner, diantaranya yakni berdirinya gerakan nasionalis Islam yang diwakili oleh Sarekat Islam, gerakan nasionalis radikal diwakili Indische Partij dan Insulinde, serta gerakan sosial Marxis Partai Komunis Hindia Belanda. Penelitian ini menggunakan metode studi kepustakaan untuk menjelaskan konstelasi pergerakan anti-kolonialisme dalam perspektif Smelserian. Penelitian ini menunjukkan bahwa gerakan sosial di Indonesia pada awal abad ke20 muncul karena ketidakpuasan terhadap struktur sosial yang ada. Indisce Partij, misalnya,
\end{abstract}


berani mendeklarasikan diri sebagai partai politik bagi semua kelompok etnis di Indonesia dan bekerjasama dengan Sarikat Islam yang merupakan organisasi Islam besar saat itu. Demikian halnya dengan munculnya gerakan komunisme yang awalnya dibawa oleh segelintir orang Belanda, mulai berani menyuarakan tuntutannya secara lebih radikal dalam menentang imperialisme dan kapitalisme Belanda di Indonesia. Inilah embrio-embrio perlawanan politik yang mewarnai konstelasi sejarah bangsa Indonesia menuju cita-cita kemerdekaannya.

Kata Kunci: nasionalisme, organisasi massa, gerakan sosial, Smelser

\section{PENDAHULUAN}

Sekelompok pemuda Jawa dengan baju ciri khas tahun 1900-an awal lengkap dengan beskap penutup kepala sebagai ciri khasnya tampak sedang menyanyikan sebuah lagu dengan bersemangat. "Bangunlah kaum yang tertindas, bangunlah kaum yang lapar," begitu sekelumit petikan syair lagu Internationale yang merupakan lagu kaum Marxist revolusioner. Diantara para pemuda tersebut adalah Darsono dan Semaoen, yang merupakan murid dari Ketua Sarekat Islam H.O.S Tjokroaminoto. Itulah sekelumit gambaran dalam film "Cokroaminoto" karya Garin Nugroho.

Lahirnya gerakan revolusioner pada saat itu disebabkan oleh beberapa faktor penyebab. Pertama, munculnya organisasi-organisasi massa di pulau Jawa, diantaranya berdirinya gerakan nasionalis Islam. Kedua, meningkatnya jumlah kalangan terpelajar karena perkembangan kapitalisme. Termasuk dalam kalangan ini sejumlah orang Eropa yang menyesuaikan diri dan ikut mendukung perjuangan kemerdekaan Hindia Belanda. Kecepatan menakjubkan berdirinya partai-partai dan sarikat buruh menunjukkan ciri perkembangan periode revolusiner. Kaum buruh di negara-negara maju mengikuti dengan sungguh- sungguh perkembangan kuat gerakan pembebasan tersebut dalam segala bentuknya dimana pun terjadi dan mendapatkan inspirasi.

Peran kaum muda terpelajar tentu sangat penting sebagai motor penggerak perubahan saat itu dan tentu saja para pemimpinnya yang berciri kharismatik dan pandai berpidato. Ssalah satunya adalah Haji Oemar Said Tjokroaminoto. Pemimpin dari Sarikat Islam (SI) pada tahun 1912, yang sebelumnya adalah perkumpulan pedagang batik atau Sarikat Dagang Batik (SDI) di Solo yang bertujuan awal sebagai organisasi yang bertujuan melindungi anggotanya dari persaingan dengan pedagang Cina yang kemudian semakin populer dan menjadi gerakan politik massa.

SI banyak terlibat dalam kehidupan sosial, ekonomi maupun keagamaan masyarakat Jawa. Tujuan organisasi pun lebih luas untuk meningkatkan taraf hidup dan perekonomian masyarakat indonesia secara umum, mengingat kemiskinan yang semakin meningkat akibat lonjakan jumlah penduduk dan semakin sedikitnya lahan pertanian yang menganggur dan terbagi-bagi dalam kepemilikan kecil-kecil. Penduduk di 
pedesaan semakin tergantung dengan pekerjaan di perkebunan dengan sistem bagi hasil atau mencari pekerjaan di kotakota.

Perubahan sosial juga dipengaruhi oleh kebijakan pemerintah lolonial pada saat itu yaitu politik etis, dengan tujuan untuk memperbaiki kondisi sosial ekonomi rakyat indonesia serta mempersiapkannya untuk bekerjasama dengan orang Eropa (Belanda) dalam memerintah negara jajahan. Hal ini berakibat pada keterlibatan langsung pemerintah kolonial dalam urusanurusan Indonesia. Sebelum itu Belanda memerintah secara tidaklangsungmelalui struktur sosial tradisional masyarakat Indonesia. Setelah adanya tanam paksa (Cultuur Stelsel 1830), Belanda menjadi kaya raya, maka muncullah suatu usul dari van Deventer tahun 1900, yang disebut "Politik Etis" atau politik balas jasa, yang isinya agar Belanda membalas budi kepada rakyat Indonesia dalam bentuk edukasi (pendidikan), irigasi (pengairan), dan emigrasi (perpindahan penduduk).

Politik Etis lahir sebagai sebuah tanggapan dari adanya sistem eksploitasi yang telah diterapkan oleh pemerintahan Belanda di Indonesia. Pada kenyataannya, dalam pidato kenegaraan di hadapan Dewan Perwakilan Rakyat Belanda pada tahun 1901, Ratu Wilhelmina mengemukakan, bukannya melihat tanah jajahan sebagai daerah kekuasaan dan sapi perahan yang menghasilkan keuntungan, Politik Etis mengisyaratkan sejumlah sumbangan dari pihak pemerintahan kolonial Belanda bagi pengembangan sekolah-sekolah dan pelayanan kesehatan, transportasi, dan pengembangan infrastruktur lainnya bagi penduduk pribumi (Himawan, 2011: 3).

Dengan adanya Politik Etis, administrasi model Eropa mulai diterapkan secara besar-besaran, pelayanan-pelayanan teknis dibuat dan penguasa asing mulai turut campur tangan secara langsung bahkan hingga ke daerah-daerah, sehingga memunculkan kewaspadaan orang-orang Indonesia terhadap keberadaan orang-orang Eropa itu. Di sisi lain, hal ini juga menurunkan pengaruh penguasa tradisional baik secara langsung maupun sebagai akibat upaya pemerintah dalam modernisasi sistem administrasi.

Pada masa yang sama peran perekonomian orang Eropa di Hindia Belanda meluas dengan cepat, hal itu menimbulkan dikotomi antara sektor modern dan tradisional dalam perekonomian. Kekontrasan tersebut tampak jelas terjadi di Jawa Tengah dan Jawa Timur. Keduanya merupakan daerah pertanian yang maju dan sangat penting, Tempat perusahaan-perusahaan orang barat dan pemerintah Belanda melakukan penetrasi mendalam. Banyak perkebunan berdiri di situ, utamanya perkebunan tebu yang berkembang dengan cepat setelah peralihan abad. Komoditas ini mejadi andalan ekspor Indonesia sebelum terjadinya Depresi Besar.

Perkebunan tebu biasanya berbagi pengairan dengan persawahan penduduk. Perkebunan tidak memiliki lahan sendiri tetapi menyewa dari penduduk yang memiliki lahan di sekitar pabrik gula dengan pergantian porsi lahan tergantung musim tanam. Sektor modern dan tradisional menjadi saling terkait, lahan tebu meluas dan 
disekitarnya adalah pedesaan yang berkembang menjadi daerah padat penduduk akibatnya banyaknya pendatang yang mencari pekerjaan di perkebunan. Sementara itu para pemilik lahan terus saja menaikkan sewa tanah karena beban pajak dan utang yang harus mereka tanggung.

Banyaknya populasi di suatu lahan serta ketergantungan pemilik tanah pada penyewa- penyewanya menciptakan suatu kondisi yang sangat riskan dengan pertikaian dan kekerasan. Pemerintah kolonial yang menjalankan Politik Etis mengeluarkan peraturan-peraturan baru tentang relasi antara pemilik dan penyewa lahan serta mengenai pengembangan ekonomi suatu wilayah. Akan tetapi manfaat kebijakan tersebut tidak pernah dirasakan oleh rakyat, bahkan sebaliknya. Perbaikan jalan dan irigasi sama artinya dengan kenaikan pajak untuk perawatan fasilitas tersebut dan penambahan kegiatan pemerintah berarti pajak jangka panjang yang lebih besar.

Peran tokoh tradisional di pedesaan tidak mampu melakukan mediasi antara penduduk desa dengan berbagai unsur gangguan dari luar. Mereka nampak sama sekali tidak berdaya dihadapan kekuatan Eropa yang superior dan dengan pihakpihak yang ditenggarai dekat dengan penguasa kolonial atau juga para pemilik perkebunan. Mereka juga tidak memiliki kemampuan menguasai peraturan dn kehendak yang dipaksakan kepada penduduk desa. Akibatnya orang mulai mencari tokoh lain di luar pemimpin tradisional untuk menjadi wakil dan pemimpin mereka, dan nampaknya SI merupakan alternatif yang menjanjikan. (McVey, 2010: 13-15).

\section{METODOLOGI PENELITIAN}

Penelitian ini bersifat deskriptif dengan studi kepustakaan yang menjelaskan sejarah pergerakan melawan kolonialisme dengan munculnya organisasi massa dan pemimpin dan ideologi politiknya dalam perspektif teori Smelserian. Metode kepustakaan atau dikenal sebagai studi literatur adalah metode yang menekankan pada penggunaan literatur dari berbagai sumber baik buku, jurnal, majalah atau koran yang memiliki relevansi dengan rumusan masalah yang diangkat dalam penelitian (Wiratha, 2006: 150).

\section{RUMUSAN MASALAH}

Faktor-faktor apa sajakah yang mempengaruhi bangkitnya kesadaran kaum bumi putera untuk berorganisasi dan melakukan gerakan sosial dan perlawanan secara politik terhadap pemerintah kolonial atau penjajah Belanda saat itu.

\section{Teori Gerakan Sosial dan Perspektif Konflik Smellser Teori Gerakan Sosial}

Gerakan sosial adalah kegiatan untuk menentukan suatu tatanan baru dalam kehidupanbersama(McLaughlin, 1969:8). Awal kemunculan gerakan sosial ditandai dengan kondisi yang penuh kegelisahan karena perasaan ketidakpuasan terhadap kehidupan sehari-hari dan dikarenakan adanya keinginan dan harapan untuk dapat meraih tatanan kehidupan baru tadi. Gerakan sosial merupakan suatu usaha yang sengaja diadakan oleh sekelompok individu yang terorganisir untuk menciptakan terjadinya perubahan dalam pola interaksi di masyarakat. 
Menurut Ritzer paling tidak ada lima karakteristik yang terdapat pada suatu gerakan, yaitu:

1. Suatu gerakan melibatkan sebagian besar individu yang berusaha memprotes suatu keadaan. Agar dapat dikategorikan suatu gerakan, maka usaha sejumlah individu tadi harus memiliki persyaratan dasar dari suatu organisasi.

2. Suatu gerakan harus mempunyai cakupan yang relatif luas. Gerakan tersebut mungkin berawal dari cakupan yang kecil tetapi akhirnya harus mampu mempengaruhi sebagian warga masyarakat.

3. Gerakantersebutdapatmenggunakan berbagai macam taktik untuk mencapai tujuannya. Taktik-taktik tadi bervariasi dari yang sifatnya tidak menggunakan kekerasan sampai dengan yang menggunakan kekerasan.

4. Meskipun dalam gerakan didukung oleh individu-individu tertentu, namun tujuan akhir gerakan tersebut adalah mengubah kondisi yang ada pada masyarakat.

5. Gerakan tersebut merupakan suatu usaha yang secara sadar dilakukan untuk mengadakan perubahan, dan bagi mereka yang terlibat di dalamnya mungkin tidak menyadari segala tindakannya tetapi mereka tetap mempengaruhi tujuan utama gerakan tadi (Ritzer, 1979: 553-554).

Berkaitan dengan rasa ketidakpuasan atau kekecewaan yang dapat menyebabkan munculnya suatu gerakan, maka perlu disimak konsep tentang breakdown-deprivation dan solidarity mobilization (Hagedorn, 1983: 516-522). Breakdown-deprivation menunjukkan kepada rombaknya susunan masyarakat tradisional sebagai akibat dari perubahan sosial yang cepat. Struktur sosial yang tidak terorganisasi, ledakan jumlah penduduk dan ketidak-seimbangan lingkungan dapat mengakibatkan terjadinya akumulasi ketegangan, frustasi, rasa tidak aman, dan kemudian pada gilirannya akan mengakibatkan timbulnya perasaan yang sangat tertekan yang cenderung dapat meledak menjadi kekerasan atau kekacauan. Konsep ini tidak dapat dipisahkan dari konsep relative deprivation (Gurr, 1970: 13) yang menunjukkan adanya ketidaksesuaian antara value expectations dan value capabilities.

Value expectations adalah kondisi kehidupan di mana masyarakat merasakan haknya untuk dapat memiliki. Sedangkan value capabilities adalah kondisi dimana masyarakat merasakan bahwa mereka mempunyai kemampuan untuk meraih apa yang diharapkan. Kekurangan yang melekat pada konsep breakdown-deprivation ini mengakibatkan konsep pendukungnya yaitu solidaritymobilization. Konsep ini menyatakan kesetujuannya bahwa perasaan bertambahnya perasaan tidak puas dan keluhan-keluhan yang cukup mendalam terhadap kondisi yang ada merupakan hal yang penting untuk menjelaskan muncul dan berkembangnya suatu gerakan. Akan tetapi penganut konsep ini mengklaim bahwa suatu gerakan mungkin tidak akan muncul walaupun ada perasaan tidak puas di kalangan masyarakat. Hal ini 
dimungkinkan karena kemampuan untuk bertindak secara kolektif relatif lemah dan kemungkinan untuk berhasilnya tindakan bersama sedemikian kecil. Dari berbagai penjelasan yang ada, sebenarnya dapat disimpulkan bahwa suatu gerakan dapat muncul dan berlangsung apabila terpenuhi tiga syarat minimal yaitu:

1. Adanya rasa ketidakpuasan atau kekecewaan terhadap keadaan yang ada pada saat ini.

2. Harus ada harapan hari depan yang lebih cerah yang muncul dari rasa ketidakpuasan atau kekecewaan tadi.

3. Adanya kemampuan atau daya untuk menggapai harapan hari depan yang cerah tadi (Haryanto, 1997: 7).

\section{Teori Konflik Smellserian}

Munculnya suatu gerakan mempunyai beberapa tahap. Merujuk dari konsep value-added-nya Smelser, maka tahap-tahap munculnya gerakan dapat diringkas sebagai berikut:

\section{Pernyataan spontan tentang ketidakpuasan bersama}

Suatu gerakan berawal ketika orang merasa tidak puas terhadap struktur sosial yang ada. Sebagian di antara mereka kemudian mengelompokkan diri dan menyatakan pandangan tentang ketidakpuasannya. Pada tahap ini suatu gerakan masih menampakkan diri sebagai tindakan bersama yantg bersifat spontan. Fungsi essensial dari tahap ini adalah untuk menarik perhatian massa yang diharapkan memberikan dukungan bagi berlangsungnya suatu gerakan.

\section{Pemilihan pemimpin gerakan}

Tahap ini berawal ketika beberapa individu menyatakan bahwa perubahan yang diusulkan mempunyai peluang untuk berhasil. Mereka ini biasanya akan berperan sebagai pimpinan mereka mulai memberi arah bagi berlangsungnya gerakan. Selain itu mereka harus mampu mempengaruhi tindakan para pengikutnya. Adapun fungsi yang esensial dari tahap ini adalah diterimanya beberapa individu sebagai pimpinan gerakan.

\section{Transformasi tindakan tidak terstruktur menjadi tindakan yang terorganisir}

Tahap ini juga sering disebut sebagai periode pengorganisasian dan perencanaan. Pada tahap ini tindakan yang spontan dan tidak terstruktur ditransformasikan menjadi tindakan yang terorganisir. Sehubungan dengan hal ini tersebut peran pimpinan pada tahap ini menjadi sangat penting. Pimpinan harus mampu merumuskan tujuan gerakan secara menyeluruh, dan mampu pula merumuskan tujuan- tujuan antara yang membimbing tercapainya tujuan akhir dari suatu gerakan.

\section{Konfrontasi dengan "lawan" gerakan}

Pada tahap ini gerakan sampai pada puncak keseriusan dalam mengajukan tuntutan dan kepentingannya, serta berupaya sekuat mungkin demi diterimanya tuntutan tadi. Tahapini dapat merupakan suatu periode yang singkat, tetapi dapat juga merupakan suatu periode yang panjang. Periode singkat apabila "lawannya" dapat dengan segera menyelesaikan permasalahan yang 
dihadapi, dan merupakan periode yang panjang apabila keduanya sama-sama mempunyai kekuatan yang seimbang dan tidak ada pihak yang bersedia untuk mengalah dalam menyelesaikan permasalahan yang dihadapi.

\section{Pencapaian hasil}

Tahap ini merupakan periode di mana dapat disaksikan apakah gerakan mampu atau tidak mencapai sasaran tujuan yang telah dicanangkan sebelumnya. Jika gerakan sukses biasanya diperlukan waktu yang cukup untuk menyebarluaskan pola tindakan yang baru ke seluruh lapisan masyarakat. Akan tetapi jika gerakan tidak berhasil, biasanya akan diikuti dengan tindakan pembubaran diri dari partisipan gerakan. Dan tidak tertutup kemungkinan mereka akan merumuskan kembali tujuan yang telah dicapai serta mencoba meraihnya melalui gerakan yang baru sama sekali (ibid: 9).

Dalam menganalisa suatu gerakan sosial haruslah dipahami perbedaannya dengan perilaku kolektif. Menurut Mohtar Mas'oed perilaku kolektif adalah kegiatan yang relatif spontan, melibatkan sejumlah besar orang dan cenderung menyebar dari norma-norma yang berlaku. Perilaku kolektif bisa muncul dalam berbagai bentuk, mulai dari gerakan sosial yang terorganisasi rapi sampai kerumunan tak beraturan, seperti orang yang berjalan di terminal bus menjelang lebaran, kerusuhan akibat berbagai hal dan sebagainya. Gerakan sosial pada dasarnya mempunyai tiga ciri:

1. Memiliki pengorganisasian internal yang lebih rapi
2. Berlangsung lebih lama, bisa sampai bertahun-tahun

3. Secara sengaja bertujuan melakukan reorganisasi atas kehidupan masyarakat (Mas'oed, 1997: 43-53).

Pada model masyarakat yang masih pra-industrial, dimana tradisi yang kuat bisa mempersatukan mereka, gerakan sosial jarang sekali muncul. Namun, pada masyarakat yang semakin majemuk dimana sub-kultur dan kontra kultur berkembang-biak, mudah sekali berkembang gerakan-gerakan sosial mengenai berbagai isu publik.

Berdasar keluasan perubahan sosial yang dicakupnya (yaitu melibatkan sebagian kecil penduduk atau seluruh masyarakat), dan kedalaman atau intensitas perubahan itu (yakni perubahan di tingkat permukaan saja atau transformasi besar-besaran), menurut David F. Aberle (Macionis, 1999: 589-611) bisa diklasifikasikan empat jenis tipe gerakan sosial sebagai berikut:

\section{Gerakan sosial alternatif}

Gerakan ini bertujuan melakukan perubahan terbatas hanya menyangkut individu-individu tertentu saja, yaitu mendorong mereka untuk meninggalkan sikap dan prilaku tertentu dan menggantinya dengan sikap dan perilaku alternatif.

\section{Gerakan sosial penyelamatan}

Gerakan ini juga mengarahkan perhatian pada beberapa individu, tetapi berusaha merubah kehidupan mereka secara radikal. Hasil tranformasi seperti kadang-kadang bisa begitu besar sehingga individu yang jadi sasaran 
itu digambarkan seperti mengalami kelahiran kembali. Gerakan-gerakan fundamentalis agama seringkali melakukan ini.

\section{Gerakan sosial reformatif}

Gerakan ini berusaha melakukan perubahan terbatas pada seluruh masyarakat. Berbagai gerakan yang menganjurkan hidup sehat, peningkatan kesadaran hukum masyarakat, perlindungan konsumen, penghormatan pada hak-hak wanita, gerakan pelestarian lingkungan hidup, dan sebagainya merupakan contoh-contoh gerakan sosial reformatif.

\section{Gerakan sosial revolusioner}

Ini adalah gerakan yang bertujuan melakukan tranformasi secara mendasar yang meliputi segenap anggota masyarakat. Gerakan semacam ini kadangkala muncul dengan rencana yang spesifik tetapi kadangkala juga muncul dengan impian utopis. Tetapi, punya rencana konkrit atau tidak, gerakan ini menolak lembaga-lembaga sosial yang ada dan memaksakan alternatif yang betul-betul berbeda. Gerakan ini bisa muncul di kalangan politik sayap kiri maupun kanan, bisa menentang pemerintahan kapitalis maupun sosialis.

\section{Masa-Masa Kebangkitan Nasionalisme: Sarikat Islam (SI)}

Dimulai dari kelas pedagang perkotaan, SI kemudian menyebarkan pengaruhnya secara cepat pada kaum lebih miskin di kota-kota, kemudian juga memperoleh pengikut luas dari daerah pelosok. Pertumbuhan SI yang demikian luar biasa bahkan melahirkan histeria sebagai bentuk harapan masyarakat kelas bawah beserta segala macam keluhan dan kegelisahan dengan harapan mendapatkan pemecahan. Tjokroaminoto dianggap banyak orang sebagai sosok Ratu Adil yang diramalkan secara tradisional sebagai pemimpin ketika rakyat sangat membutuhkan.

Semakin meluasnya ekspansi SI dan daya tariknya bagi kaum petani tidak berpendidikan, mau tidak mau membuat orang-orang Eropa menaruh perhatian. Mereka khawatir, dengan asumsi akan muncul seseorang yang mendapat banyak dukungan. SI akan dapat memotong saluran mapan penguasa dan masyarakat serta mengayunkan kapak berbahaya diantara administrasi penjajahan dengan rakyat. Sanjungan berlebihan terhadap Tjokroaminoto serta karakter organisasi yang kacau dan tak teratur SI dianggap sebagai faktor potensi eksplosif, bahkan orang Eropa yang bersimpati atas kebangkitan umum Indonesia pun nampaknya merasa harus memperhatikan perkembangan pergerakan tersebut (McVey, 2010: 15).

Hal yang kurang nampak tapi perlu diwaspadai menurut mereka adalah bahwa SI merupakan organisasi keagamaan. Belanda telah membangun sistem kekuasaan mereka dengan memerintah secara tidak langsung berdasarkan struktur adat sebelum Islam serta mendukungnya, jika perlu melawan mereka yang mengklaim sebagai pemimpin Islam bagi rakyat sekitar secara umum untuk membatasi kekuatan Islam di Nusantara. Mereka menyadari dengan meremehkan kepemimpinan Islam hingga akhirnya pecah Perang Aceh yang baru saja usai, serta hadirnya Pan-Islamisme sebagai kekuatan dinamis di Asia. Hal tersebut muncul dengan 
hidupnya kembali semangat keagamaan di Jawa sebagai dampak pengajaran Islam modern yang menghasilkan gerakan-gerakan perjuangan, sehingga semuanya serba mungkin. Walaupun konsep tentang bangsa Indonesia belum ada saat itu, umumnya orang di seluruh Nusantara belum berpikir kearah tersebut. Islam muncul sebagai sumber pencetus persatuan melawan penguasa asing. Karena itu Belanda mulai sangat berhati-hati ketika berurusan dengan SI (McVey, 2010: 16).

Pengikut Sarekat islam (SI) terdiri dari orang-orang yang dipersatukan oleh agama dan profesi. Pergerakan ini kemudian juga menarik kaum santri yang berharap SI akan menggalakkan intrepretasi keagamaan kaum modernis yang menjadi populer di kalangan kaum pedagang di perkotaan maupun kelompok-kelompok lama, tetapi juga sekaligus merangkul kelompok Islam abangan di Jawa yang keyakinan Islamnya bercampur dengan kepercayaan pra-Islam, serta berseberangan dengan kaum santri yang menginginkan praktik Islam lebih konsekuen. Hal ini didukung dengan kaum priyayi rendahan yang keberatan dengan konservatisme kesultanan Surakarta. Selain itu, mereka juga memperoleh dukungan dari kaum tradisionalis yang menentang Westernisasi ala Budi Utomo (BU), suatu pergerakan progresif yang dibentuk kaum priyayi muda Jawa pada tahun 1908.

Singkatnya, SI merupakan organisasi yang heterogen. Dan fakta itu menunjukkan adanya krisis dalam masyarakat yang menginginkan terjadinya perubahan mendalam. Luasnya cakupan SI membuat mereka yang memiliki berbagai perbedaan tetapi sama-sama merasakan ketidakpuasan turut ambil bagian dalam organisasi ini dalam bentuk bertentangan. Hal inilah yang membuat para pemimpin SI kesulitan dalam mengarahkan pergerakan, sedang pihak pemerintah sendiri mengembangkan kebijakan saling bertaut. Terlebih yang dianggap paling berbahaya oleh penguasa dalam situasi keresahan yang digeneralisasi, SI telah menyatukan kaum modernis dan tradisionalis, santri dan abangan Jawa, serta Jawa dan non-Jawa yang mungkin saja semua akan berbalik melawan penguasa asing dengan seluruh kesadaran.

Bagi mayoritas penduduk Eropa yang tinggal di Indonesia atau Hindia Belanda saat itu, SI muncul sebagai kekuatan mengancam yang tidak dapat dibiarkan oleh pemerintah. Jumlah penduduk Belanda telah meningkat tajam sejak akhir abad ke-19 M dan kebanyakan pendatang baru tersebut menganggap Indonesia hanya sebagai tempat tinggal sementara sehingga mereka sama sekali tidak tertarik dengan Politik Etis yang bagi mereka hanya akan menciptakan perkembangan bagi penduduk lokal dan akan mengancam kesejahteraan mereka.

Binnenlands Bestuur, yaitu orang orang Eropa yang menjadi penguasa sipil serta mendominasi birokrasi yang dijalankan oleh kaum priyayi indonesia, adalah para pejabat yang paling tidak menginginkan adanya toleransi bagi SI. Mereka menganggap Politik Etis yang diasumsikan akan mengurangi ikatan tradisional, perluasan pendidikan serta meningkatnya kesadaran orangorang Indonesia akan berakibat pada evolusi bertahap dalam masa magang 
persahabatan Indonesia dengan Belanda.

Mereka menyatakan hal itu tidak realistik dan berbahaya karena orang Indonesia akan berubah dari dominasi adat masuk ke dalam para pemimpin penghasut. Karena itu rakyat Indonesia harus terus berada dalam kantong tradisionalisme, karena sekali mereka berhasil keluar maka akan menjadi kekuatan revolusioner. Menurut kaum konservatif merupakan tugas Gubernur Jenderal Idenburg untuk melarang Sarikat Islam sebagaimana ia akan menghentikan Indische Pertij (IP) pada 1912.

Idenburg ternyata memandang SI sebagai sesuatu yang sangat berbeda dengan IP. Organisasi tersebut jelas merupakan organisasi revolusioner sementara SI sama sekali tidak menunjukkan sikap tidak loyal, apalagi mereka merujuk pada penduduk Eurasia, karenaya dianggap tidak mewakili opini bangsa Indonesia keseluruhan. SI justru merupakan suatu langkah maju penerapan Politik Etis, "Kita harus memanfaatkannya bahkan jika kita menemukan kesulitan sekalipun. Kita menginginkan hal ini setidaknya kita lakukan dan telah kita dorong melalui pendidikan kita."

Pergerakan tersebut menurutnya dapat berfungsi sebagai penengah bagi pengusaha, pemilik perkebunan dan pejabat pemerintah. Sebagai "Biro Keluhan" mungkin akan dapat berfungsi sebagai katup pengaman dalam mengurangi frustasi publik serta sebagai indikator keresahan setempat. Karena penguasa tradisional tidak mampu lagi mewakili dan mengarahkan rakyat dan organisasi populer seperti SI mungkin dapat membantu menggantikan peran mereka (McVey, 2010: 18).

Gubernur Jenderal kemudian menunjukkan langkah ramah terhadap gerakan baru tersebut. Meski ia didukung oleh menteri jajahan dan parlemen Belanda, sebagian besar orang Belanda di Indonesia menjadi lebih waspada dan beranggapan pemerintah telah membuka jalan bagi terjadinya kekacauan. Bagi mereka SI kependekan dari "Salah Idenburg". Berbagai rumor tentang konspirasi pribumi bermunculan: SI sedang merencanakan pemberontakan, keraton Surakarta secara rahasia berada di belakang mereka, bahwa polisi pribumi menekan para buruh perkebunan untuk bergabung dalam gerakan, bahwa buruh Kereta Api Indonesia merancang pemutusan komunikasi pada saat pemberontakan terjadi. Selama beberapa bulan orang-orang Belanda dilanda kepanikan dan hampir seluruh perusahaan gula membuat berbagai persiapan menghadapi serangan. Bahkan beberapa diantara mereka menyiapkan persenjataan.

\section{Sneevliet Propagandis Marxis}

Di tengah berbagai polemik dan kekhawatiran seputar kebangkitan SI, seorang pemimpin buruh Belanda bernama Hendricus Josephus Fransiscus Sneevliet tiba di Indonesia. Sneevliet datang ke Indonesia hanya sekedar mencari pekerjaan, tetapi rasa panggilan revolusionernya membuatnya tak terhindarkan bahwa kegiatan utamanya adalah memberikan pidato akan keyakinan politiknya.

Semangat Sneevliet mendesak rekan-rekannya bersepakat dengan 
dirinya. Secara kronis ia tidak mampu melakukan kompromi, tetapi pada saat yang sama ia juga tidak pernah merasa sangat yakin tentang intrepretasinya mengenai keyakinan sosialis yang harus kebal terhadap perubahan nilai. Dalam hal ini, Sneevliet mengikuti kemelut hati nuraninya sendiri ketimbang politik daruratnya. Ia tetap seorang revisionis SDAP ketika sejumlah rekan Marxis radikal memisahkan diri dan membentuk SDP yang melahirkan Partai Komunis Belanda. Pada 1912, Sneevliet ternyata beralih kepada kelompok radikal tersebut saat kaum reformis menolak mendukung demonstrasi kaum buruh pelabuhan di Amsterdam.

Perseteruannya dengan kaum moderat membuatnya kehilangan pekerjaan, karena sebelumnya Sneevliet menjabat Ketua Sarikat Buruh Kereta Api (NVSTP) dibawah kontrol SDAP. Tidak ada lagi pekerjaan sejenis yang ada di Belanda karena kebanyakan swasta tidak akan memperkerjakan seorang penyulut api tersohor seperti dirinya, ia kemudian memutuskan mencari peruntungan ke Indonesia. Sebelum meninggalkan Belanda, Sneevliet merasakan kekecewaan lantaran keputusan SDP untuk turut dalam pemilihan umum dan ikut bersaing dengan bersama partai revisionis. Menurut pendapatnya hal ini akan memecah perolehan suara partai sosialis tetapi akhirnya ia memilih tetap berafiliasi dengan SDAP. Sepanjang masa tinggalnya di Indonesia terlepas dari kegiatan revolusionernya, ia tetap menjadi anggota SDAP yang moderat dan tidak dalam gerakan proto-komunis. Suatu keberuntungan bagi Sneevliet, karena orang-orang Eropa terdidik ketika itu sedang diperlukan di Indonesia sedangkan latar belakang politiknya tidak menjadi halangan. Mulanya ia bergabung dengan staf editorial di Soerabajaasch Handelsblad, koran utama Jawa Timur, corong penting sindikat perusahaan gula. Tidak berselang lama, seorang rekan sosialis, DMG Koch mundur dari pekerjaannya sebagai sekretaris Asosiasi Dagang di Semarang (Semarang Handelsvereniging) dan menunjuk Sneevliet sebagai penggantinya. Kepindahannya ke ibukota Jawa Tengah tersebut secara politis sangat menguntungkan karena Semarang menjadi pusat perkembangan kota yang pesat, kemudian menjadi ajang kegiatan radikal di Hindia Belanda.

Suasana kota Semarang saat itu terasa lebih liberal dibanding kota-kota besar lain di Jawa, sebagian karena Semarang menjadi pusat kepentingan komersial orang-orang Eropa yang hendak membangun pasar di Jawa, dan memandang tepat tujuan Politik Etis dalam meningkatkan standar hidup orang Indonesia. Para majikan Sneevliet berkepentingan terhadap barang barang impor, perumahan, bank dan perusahanperusahaan manufaktur. Selanjutnya hubungan mereka dengan sekretaris baru berjalan dengan sangat lancar. Selama jam kerjanya ia melakukan tugasnya dengan baik dalam mempromosikan kapitalisme, sementara tidak ada yang berkeberatan dengan aktivitas sosialnya di luar itu. Ia hanya diminta untuk tidak melakukan upaya yang mengarah pada revolusi, itulah sebenarnya yang sedang dirancang oleh Sneevliet.

Semarang menjadi Pusat Serikat Buruh Kereta Api di Indonesia (VSTP). Secara alamiah Sneevliet tertarik 
mengingat kemiripan organisasi tersebut dengan yang ada di Belanda sebelumnya. VSTP merupakan salah satu organisasi buruh tertua di Indonesia yang dibentuk lima tahun sebelumnya. Saat itu organisasi ini sedang berkembang, VSTP merupakan organisasi yang terbuka bagi buruh Indonesia maupun Belanda. Dalam satu tahun setelah kedatangan Sneevliet di Semarang ia berhasil membawa organisasi tersebut ke jalur yang lebih radikal yang mengarahkan tujuan mereka untuk memperbaiki nasib buruh tidak terlatih dan miskin.

Awal 1914, Sneevliet merangkap bekerja penuh di lingkungan kapitalis sebagai editor koran VSTP, De Volhading. Pada saat yang sama ia sibuk belajar bahasa Indonesia dan Jawa terutama untuk menyebarkan keyakinanya pada penduduk setempat. Baginya hal ini masih belum cukup untuk memenuhi kehendaknya memperluas pengaruh sosialisme. Ia merasa kerja nyata hanya dapat dilaksanakan dengan cara menghimpun seluruh kaum sosialis yang sudah ada di Hindia Belanda. Maka atas prakarsanya suatu kelompok yang terdiri dari 60 orang sosial demokrat mendirikan Indische SocialDemocratische Vereniging (ISDV) pada 9 Mei 1914 di Surabaya.

ISDV yang kemudian menjadi Partai Komunis Indonesia, pada pertemuan awal tersebut diragukan sifat Indonesia ataupun Komunisnya. Hampir seluruh yang hadir orang Belanda, sejumlah orang Eurasia dan Indonesia hanya sebagai latar belakang, sebagian anggota pemuda pengikut SDAP dan bukan dari saingan radikal mereka. Hampir semua yang hadir adalah orang-orang yang menjadi sosialis ketika masih di Belanda dan kemudian datang ke
Indonesia sebagai imigran baru. Reaksi mereka terhadap kondisi sosial wilayah jajajahan yang sepenuhnya tidak mereka kenal sangat beragam dengan perbedaan tajam. Sebagian membuang Marxisme dalam hubungannya dengan kondisi Indonesia. Mereka mendukung Politik Etis dengan perubahan berangsur sebagai sesuatu yang harus dilakukan terhadap masyarakat demikian terbelakang. Sebagian yang lain memandang sistem kolonial yang demikian tidak adil dan berpendapat dapat menerapkan prinsipprinsip revolusioner terlepas dari tahap perkembangan negeri. Kelompok yang lebih kuat ini alih-alih mengikuti garis moderat rekan mereka di Eropa, tenaga penggerak utama ISDV mengarah ke ekstrem kiri. Hal ini merupakan kenyataan penting yang dapat dilihat dari pertemuan pertama mereka, kelompok moderat dan radikal terpecah sejak mula dalam membicarakan fungsi organisasi (McVey, 2010: 22-23).

Kelompok kanan berharap organisasi ini akan menjadi pusat pertukaran gagasan antara kaum sosialis Eropa di Indonesia serta memberikan bahanbahan temuan mereka bagi kelompok sosialis di parlemen Belanda. Menurut mereka tidak tepat jika ISDV turut campur dalam kehidupan politik di Indonesia, terutama karena mereka sama sekali tidak memiliki pengetahuan yang cukup tentang masyarakat Indonesia maupun kecakapan Bahasa Indonesia yang akan digunakan untuk mengkomunikasikan pengaruh mereka terhadap orang-orang Indonesia. Terlebih bagi mereka percaya akan teori evolusioner bahwa sosialisme hanya akan berarti dalam konteks negara dengan industri berkembang yang 
melahirkan kaum proletariat. Agitasi sosialis bagi Indonesia yang berada dalam tahap pra-kapitalisme sama sekali tidak berguna dan yang paling buruk ialah memberikan dukungan bagi elemen-elemen revolusioner perbuatan tak bertanggung jawab dalam dunia politik Indonesia.

Kaum sosialis yang sependapat dengan Sneevliet dalam memandang tugas pokok ISDV ialah melakukan propaganda prinsip-prinsip sosialisme di Indonesia. Mereka berpendapat kekuatan sosialisme dapat memiliki peran langsung di daerah koloni, terutama mendorong sikap revolusioner anti imperialisme. Setelah melalui berbagai perdebatan panas, kelompok mayoritas radikal menang. Disepakati bahwa fungsi partai ialah menyatukan kaum sosialis Hindia Belanda, menjelaskan kepada faksi sosial demokrat di parlemen Belanda mengenai kondisi Indonesia dan menyebarkan propaganda sosialisme di seluruh wilayah Indonesia.

Sejak itu cara yang dianggap paling efektif ialah dengan terlibat langsung dalam perpolitikan Indonesia. Walaupun ISDV mencakup hampir seluruh kaum sosialis di Indonesia, mereka mengalami kesulitan dalam mengembangkan organisasi. Pada 1915 hanya ada 85 anggota dan pada tahun berikutnya 134 Orang. Organisasi ini tidak memiliki cukup dana, pengaruh maupun program-program komprehensif bagi massa rakyat Indonesia. Kaum sosialis moderat nampaknya benar ketika mereka menunjukkan letak kelemahan organisasi, yaitu pada keanggotaannya yang hampir seluruhnya orang Belanda. Bila partai tersebut sama sekali tidak efektif, maka harus dicari suatu aliansi dengan gerakan besar yang dapat menjadi jembatan bagi partai dan massa Indonesia.

Untuk sementara ISDV tidak membuat suatu gerakan apa pun ke arah yang dimaksud. Sebagian karena meletusnya atau pecah Perang Dunia I yang diikuti gagalnya gerakan Internasionale kedua yang memberikan kejutan ideologis bagi kaum sosialis di Indonesia untuk beberapa waktu. Selama tahun pertama, ISDV hanya membatasi kegiatannya pada diskusi teoritis seputar kondisi dan problematika koloni serta berusaha mengumpulkan dana untuk mendukung kaum sosialis dalam pemilihan di Belanda. Pada kongres mereka pada 1915 muncul upaya kuat untuk mengalihkan sejumlah besar dana partai bagi pergerakan di Belanda. Setelah kongres, Sneevliet dan kawan-kawannya berhasil mencegah hal tersebut.

Partai kemudian berusaha memperluas pengaruh mereka melalui media dengan menerbitkan koran Het Vrije Woord, edisi pertama muncul pada Oktober 1915. Koran ini terbit dalam bahasa Belanda, hanya sedikit orang Indonesia yang membacanya. Baru dua tahun kemudian partai menerbitkan koran berbahasa Indonesia. Het Vrije Woord sudah menyediakan ruang untuk publik tempat ISDV dapat mengungkapkan pandangannya. Hal ini terbukti sangat bermanfaat bagi partai karena pada 1916 mereka memperoleh pujian dari kelompok radikal Indonesia karena sikap mereka dalam dua masalah yang membuat publik mendapatkan kesadaran politik. Salah satunya tentang penahanan seorang wartawan terkemuka Indonesia, Raden Mas Marco Kartodikromo, yang pernah menulis 
artikel kritik tentang tindakan pemerinta Hindia Belanda terhadap Sarikat Islam, dan Het Vrije Woord sebagaimana sebagian besar pers berbahasa Indonesia berpihak pada Marco.

Isu kedua yang mereka angkat ialah mengenai kampanye Indie weerbar (persenjatai orang Indonesia) kampanye untuk membangun milisi Indonesia dibawah komandoBelanda. Pada awalnya proyek ini dibuat oleh orang-orang Belanda yang khawatir terhadap gerakan Jepang dan Australia (Inggris) terhadap wilayah Nusantara selama PD I. Hal ini kemudian mendapatkan popularitas yang mengejutkan di antara orang Indonesia yang sadar politik, sejumlah orang di antara mereka memandang sebagai alat untuk membujuk pemerintah Belanda guna memperluas hak-hak politik mereka (McVey, 2010: 25).

Untuk memperluas gerakan ISDV kemudian untuk pertama kalinya beraliansi dengan Insulinde yang kemudian berkembang menjadi organisasi paling radikal saat itu dan secara politis berkembang baik sebagai organisasi non-Eropa. Pergerakan ini diawali pada 1907 sebagai asosiasi nonpolitik, berorientasi kelompok Eurasia atau Indo dan banyak mewarisi karakter Indische Partij yang dibubarkan pada 1913. Radikalisme mereka muncul karena perasan terbuang dari kaum Eurasia atau Indo Belanda setelah meningkatnya kaum Eropa yang eksklusif dan ancaman ekonomi akibat meningkatnya jumlah kaum terpelajar Indonesia yang dapat dibayar lebih murah dari kaum Eurasia.

\section{Partai Politik Radikal Pertama di Hindia Belanda: Indische Partij}

Kiprah radikal Indische Partij tidak lepas dari karakter pemimpinnya yaitu
Francois Eugene Douwes Dekker, seorang peranakan Belanda yang kelak bernama Setia Budi Danudirja. Pagi buta, 15 September 1912, Douwes Dekker atau disingkat DD tiba di Stasiun Bandung ditemani J.D Brunsveld van Hulten dan van Der Poel melakukan tur propaganda di tanah Jawa untuk menyiarkan Indische Partij, partai politik yang baru seminggu sebelumnya didirikan. Paul van Der Veur dalam buku The Lion mengambarkan, "Pidato DD yang menggugah". Orasi selesai begitu peluit berbunyi dan kereta meluncur ke Yogyakarta. Saat senja, rangkaian kereta memasuki kota Gudeg di sana, para tokoh Indische Partij disambut hangat anggota Insulinde, Boedi Utomo dan Sarekat Islam.

Malam itu juga di gelar pertemuan politik. Selain DD, pemimpin Insulinde Semarang G.L. Toope, turut menyampaikan pidato. Topik pembicaraan mereka mengenai kesetaraan ras, mereka menyoroti diskriminasi pemerintah Hindia Belanda terhadap warga negara. Sebagai peranakan, para anggota Insulinde selalu diposisikan kelas dua apalagi kaum pribumi. "Comrades! Nay, Indier," DD mengucapkan salam khas pada setiap sambutannya. Diskusi diakhiri dengan tanda tangan sekitar 60 peserta yang berniat menjadi anggota Indische Partij (Tempo, 2012: 38).

Para pemimpin Insulinde ingin mengatasi permasalahan tersebut dengan membentuk aliansi antara kelompok Eurasia atau Indo Belanda dengan kaum terpelajar Indonesia agar memperoleh hak setara dengan kaum pendatang dari Eropa, mereka kemudian mempromosikan suatu "Nasionalisme Hindia" yang bertujuan menciptakan 
identitas kebangsaan berdasarkan tempat tinggal dan bukan etnisitas.

Koalisi Indische Partij dan Insulinde semakin mengeras dalam peristiwa "geger Polanharjo," demikian peristiwa itu dikenal. Dua tokoh Insulinde yakni Mochammad Misbach, kyai dan mubalig yang juga anggota Sarekat Islam, dan Tjipto Mangoenkoesumo, terlibat dalam peristiwa ini. Tjipto juga anggota Volksraad atau Dewan Rakyat Hindia Belanda, saat itu dikenal dengan tulisannya di surat kabar "Panggoegah" yang kerap dengan tajam mengkritik pemerintah kolonial Belanda, kesultanan dan pemilik perkebunan. Tjipto adalah inteletual kritis yang memiliki pergaulan luas di kalangan priyayi. Misbach lebih progresif dibanding Tjipto.

Misbachadalahseorang propagandais ulung. Takashi Shiraishi dalam bukunya, Zaman Bergerak: Radikalisme Rakyat di Jawa 1912-1926, menceritakan bagaimana sebuah poster karya Misbach yang menggambarkan posisi buruh dalam sistem kapitalisme dan dimuat dalam majalah Islam Bergerak, 20 April 1918. Dalam poster-poster itu tertulis kata-kata menggugah kesadaran buruh. Poster yang menunjukkan persekongkolan kolonial Belanda dengan kesultanan dan pengusaha perkebunan. Sebagai kapitalis ketiganya, menurut Misbach, adalah representasi penghisap tenaga para petani dan buruh agar bisa dipekerjakan dengan keras dengan upah rendah.

Duet Misbach dan Tjipto itulah yang membuat semakin banyak penduduk yang bergabung dengan Insulinde. Pada 1919 jumlah anggota Insulinde Surakarta diperkirakan tak kurang dari 10 ribu anggota, sebagian besar adalah buruh dan petani. Sebelum didominasi massa petani, anggota Insulinde kebanyakan orang Indo atau priyayi yang akhirnya menjadi semakin setara tanpa memandang strata, ras dan agama.

Pesatnya perkembangan Insulinde Surakarta itu pula yang menbawa DD ke meja hijau. Itu karena terjadinya aksi pemogokan petani di kantong-kantong Insulinde. Pemogokan berpangkal dari persoalan upah di perkebunan tembakau Polanharjo. Mereka menuntut upah glidig bekerja sebagai buruh perkebunan dinaikkan dari sebelumnya dibayar 4 gulden. Tuntutan itu tidak dikabulkan, pemogokan terjadi dan puncaknya pada 17 Juni 1919, pabrik dan perkebunan lumpuh total. Pemerintah Belanda kalang kabut. Tjipto sendiri sudah turun tangan untuk menyelesaikan persoalan tersebut. Dia mengusulkan dibentuknya komisi untuk menjembatani tuntutan petani, dia juga berencana menggelar pertemuan Insulinde di Surakarta untuk membicarakan persoalan itu. Tapi rencana pertemuan ditentang residen Surakarta, Harloff.

Berita larangan pertemuan itu rupanya tak sampai ke petani. Pada tanggal 22 Juni 1919 pada hari yang direncanakan, sekitar 1.500 petani berbondong-bondong masuk Surakarta dengan berjalan kaki tapi di gerbang barat kota mereka dicegat polisi dan baku hantam pun terjadi. Sekitar seratus petani dan buruh ditangkap termasuk delapan pemimpin kring seperti Kartosoediri dan H. Tajib. Peristiwa itu membuat Douwes Dekker dibawa ke meja hijau dengan tuduhan menghasut petani Polanharjo (Tempo, 2012: 52-53).

Akhirnya pemerintah kolonial Belanda mengasingkan para pemimpin Indische Partij dengan tuduhan 
tulisan-tulisan di koran atau majalah yang menghasut rakyat dan menebar kebencian terhadap pemerintah yang dapat memicu pemberontakan. Titik puncaknya adalah tulisan Tjipto dan Soewardi Suryaningrat yang berjudul "Als ik eens nederlander Was" atau "Seandainya saya seorang Belanda" isinya menghujat dan mengolok-olok pemerintah kolonial yang merayakan kemerdekaan di tanah jajahan.

Dalam bukunya, Het Leven van E.F.E DouwesDekker, FransGlisenarmenuliskan, selebaran Soewardi membuat pemerintah murka, Gubernur Jenderal Alexander W.F Idenburg kemudian menangkap dan menahan Tjipto dan Soewardi. DD yang baru pulang dari Eropa mengkritik penahanan dua kawannya itu dalam koran De Express. Dalam tulisannya dia menyebut keduanya sebagai pahlawan. Empat hari kemudian DD juga ditangkap dan diputuskan dengan atas nama kebesaran hati kolonial memberi pilihan tempat pembuangan di negeri Belanda.

Setelah berlayar satu bulan melalui rute pelabuhan Genoa, Italia, ketiganya tiba di Belanda pada 2 Oktober 1913. Dalam bukunya, Orang Indonesia di Negeri belanda 1600-1950, Harry A. Poeze menceritakan ketiga tokoh ini disambut penuh hormat puluhan kader Partai Buruh Belanda, Social Democratische Arbeider Partij (Tempo, 2012: 74).

Pemimpin pergerakan menunjukkan dukungan kepada SDAP dalam kampanye mereka untuk melegalkan kembali Indische Partij dan kaum sosialis dengan senang menerimanya. Tetapi hal tersebut ternyata tidak dapat mencegah pembubaran partai dan mengusir ketiga pemimpinnya, yaitu Tjipto Mangunkusumo, E.F.E Douwes Dekker dan Suwardi Suryaningrat (Ki Hajar Dewantara) karena terlibat aktivitas yang susah diatur menurut pemerintah Hindia Belanda. Mereka dibuang ke Belanda dan disambut oleh pengikut SDAP yang berkeberatan dengan pelanggaran hak sipil yang telah dilakukan oleh pemerintah kolonial. Organisasi yang dipimpin Tiga Serangkai memiliki pengikut yang besar di kota-kota di Jawa. Semarang menjadi pusat kegiatan mereka banyak penduduk kota yang menjadi pengikutnya, organisasi ini lebih besar dari ISDV dengan jumlah 6000 anggota pada 1917 dan sangat aktif. Tambahan pula para pengikut Eurasia membuat organisasi tersebut secara kultural dan kebahasaan lebih sebagai kelompok sosialis ketimbang pergerakan Indonesia.

\section{ISDV dan Cita-Cita Negara Komunis di Indonesia}

Perpecahan aliansi mulai terjadi, Sneevliet yang awalnya sangat terkesan dengan Tjipto Mangun Kusumo kemudian mulai menyerangnya karena menganggap kurang dedikasi kepada perjuangan kelas kaum proletar. Tjipto sendiri kemudian menolak usaha Sneevliet mengubah partainya ke arah dan tujuan lebih radikal. Setahun kemudian aliansi keduanya berakhir. Pada kongresnya tahun 1916, ISDV memutuskan secara resmi kerjasama politiknya dengan Insulinde dan meminta para anggota partai untuk keluar dari Insulinde.

Bahkan sebelum kerjasamanya dengan Insulinde berakhir, kaum revolusioner ISDV telah mencari lahan politik baru yang lebih besar. Saat itu perhatian mereka tertarik pada Sarekat Islam yang pada tahun 1916 mempunyai 
ratusan ribu anggota, merupakan raksasa yang jauh lebih besar diantara gerakan politik Indonesia saat itu. Sejumlah anggota ISDV telah menjadi tokoh terkemuka SI. Beberapa pemimpin ISDV turut memberikan sambutan dalam pertemuan SI dan berdiri bersama para pemimpinnya (McVey, 2010: 28).

Dalam kongres nasional SI yang pertama di Surabaya pada tahun 1916 belum menunjukkan adanya keinginan sungguh-sungguh untuk membentuk aliansi dengan ISDV. Salah satu contohnya saat pimpinan sidang menghentikan pidato seorang pemimpin sosialis, Semaun, yang baru berpidato selama lima menit. Tetapi perasaan anti pemerintah pun mulai berkembang, pada waktu pembentukan tiga tahun sebelumnya Sarekat Islam menyatakan tunduk tanpa syarat pada pemerintah Belanda, tetapi sekarang mereka mulai menyampaikan masalah pemerintahan sendiri. Kongres mengkritik kebijakan administrasi agraria dan mewacanakan gerakan buruh. Mereka juga menyampaikan wacana penyelarasan antara prinsip-prinsip Islam dan sosialisme, sebuah wacana yang tidak hanya didukung golongan muda radikal pendukung ISDV tetapi juga oleh wakil-wakil terkemuka kelas pedagang perkotaan yang tergolong santri. "Sosialisme" kemudian dikenal sebagai suatu kata yang secara sederhana diartikan sebagai perlawanan terhadap dominasi asing dan dukungan terhadap Indonesia yang modern, sejahtera dan merdeka.

Pada kongres 1916, atmosfer revolusi dalam SI masih kecil, tetapi dalam satu tahun hal itu telah mengancam kontrol pimpinan pergerakan. Peningkatan radikalisme dalam SI saat itu sebagian mencerminkan dengan baik kesengsaraan dan ketakpastian akibat PD I yang juga berdampak bagi Indonesia. Selama perang berlangsung, terisolasinya Hindia Belanda dan terbatasnya pelayaran menyebabkan harga-harga meningkat tajam dan terjadi penurunan pendapatan di Indonesia, penurunan yang berawal pada 1914 berlanjut hingga 1924. Akibat buruk perang menambah keraguan kaum terpelajar Indonesia tentang kebaikan kontrol ekonomi kapitalis asing. Hal ini juga melahirkan kesadaran umum tentang situasi mereka yang tidak menguntungkan. Terutama seperti yang terjadi di wilayah penanaman Tebu di Jawa, para petani pemilik lahan mulai tidak puas terhadap sewa yang diberikan oleh pemilik perkebunan. Panen padi sangat buruk, impor yang menurun karena terbatasnya pelayaran karena perang menyebabkan harga bahan baku melambung, karena tekanan inflasi serta adanya kesadaran bahwa mereka bisa memperoleh harga yang baik jika menanam padi, sedangkan sewa yang selama ini mereka terima bagi lahan beririgasi mereka jauh dari memadai (McVey, 2010: 30).

\section{Pemimpin Marxis dari Surabaya: Semaoen}

Figur paling menonjol di antara kelompok Marxis Hindia Belanda pertama ialah Semaoen, yang menjadi juru bicara ISDV pada Kongres SI 1916. Ia lahir di daerah dekat Surabaya, anak seorang Pegawai Kereta Api rendahan, ia sendiri juga menjadi pegawai kereta api. Semaoen menjadi salah seorang anggota awal Sarikat Islam. Ia bergabung pada SI cabang Surabaya pada 1914 dan segera menjadi sekretaris pada Cabang 
SI tersebut. Ia banyak terlibat dalam aktivitas serikat buruh kereta api sehingga mengantarkan dirinya mendapatkan nama buruk pertama di Indonesia. Kedudukan itu juga menghubungkan dirinya dengan Sneevliet yang kemudian menjabat di VSTP. Semaoen kagum dengan upaya kaum revolusioner Eropa atas nama kaum buruh di Indonesia. Setahun kemudian ia menjadi wakil ketua cabang Surabaya. Semaoen masih sangat muda ketika muncul sebagai tokoh pergerakan revolusioner Indonesia. Pada 1916 saat memulai perjalanan politiknya, ia masih berusia 17 Tahun (McVey, 2010: 32).

Semaoen menjadi juru bicara berbakat dan penuh semangat dalam kelompok tersebut. Pada saat yang sama posisi kaum revolusioner muda SI sangat meningkat karena bergabungnya Semaoen ke dalam mesin politik yang dinamis. SI cabang Semarang berkembang pesat, pada 1916 terdapat 1.700 orang anggota setahun kemudian menjadi 20.000. Segera saja menjadi rival bagi organisasi di Surabaya. Seruannya sebagaimana diungkapkan dalam koran Sinar Djawa (kemudian menjadi Sinar Hindia) menekankan pada tuntutan-tuntutan lebih radikal dalam bidang ekonomi dan keadilan sosial.

\section{Pecahnya Sarikat Islam Menjadi Putih dan Merah}

Pada awal 1920, ISDV menerima surat dari Haring (nama samara Sneevliet) yang berada di Shanghai yang menyarankan agar bergabung menjadi anggota Komintern. Atas dasar Kongres Istimewa yang dihadiri oleh 40 orang, akhirnya diputuskan bahwa ISDV mengganti namanya pada 23 Mei 1920 menjadi Perserikatan Komunis Hindia.
Hal ini menjadi satu faktor yang menyulut perpecahan dalam tubuh SI, ketika sebagian anggota dari SI merangkap menjadi anggota Perserikatan Komunis Hindia.

Perpecahan dalam tubuh Sarekat Islam mencapai puncaknya pada saat diadakan kongres luar biasa Sentral Sarekat Islam di Surabaya pada tanggal 6-10 Oktober 1921. Pada saat itu, Semaoen habis-habisan berdebat dengan Agus Salim, tapi tidak dapat mempertahan-kan posisi kader-kader PKI di Sarekat Islam. Karena debat sepenuhnya dikuasai Agus Salim sebab Semaoen dan Tan Malaka masing-masing hanya diberi kesempatan berbicara selama 5 menit. Selain itu secara tidak langsung Semaoen melontarkan ide-ide pluralisme gerakan Sarekat Islam.

Hal ini sama artinya dengan mengusulkan perubahan asas Sarekat Islam dari "Islam" menjadi "Komunis" yang lebih plural. Lontaran ini dimanfaatkan oleh Agus Salim untuk membangkitkan sentimen agama para peserta kongres dan memberlakukan disiplin partai. Akhirnya Semaoen dan anggota Sarekat Islam yang merangkap menjadi anggota PKI secara resmi dikeluarkan dari Sarekat Islam (Sulistyono, 2004: 32-33). Akibat peristiwa tersebut Sarekat Islam pecah menjadi dua aliran, yaitu: (1) Sarekat Islam Merah (SI Merah) yang dipimpin Semaoen yang berasaskan sosial-komunis dan berpusat di Semarang dan (2) Sarekat Islam Putih (SI Putih) yang dipimpin Agus Salim yang berasaskan kebangsaan dan keagamaan dan berpusat di Yogyakarta (Tzabit, 2011).

Sejak munculnya ISDV/PKI dan Sarekat Islam Merah ciri lain dari gerakan radikal atau kiri berkisar pada ideologi 
Marxisme, meskipun demikian Marxisme memiliki berbagai rupa atau intrepretasi. Gerakan radikal kiri untuk pertama kalinya melakukan pemberontakan anti-kolonial yang meletus pada tahun 19926/1927, yang diorganisir dalam skala nasional dan dengan mudah diatasi penguasa kolonial Hindia Belanda, yang kemudian terus menjalankan perjuangannya secara bawah tanah di era Jepang dan muncul kembali di masa Revolusi dengan elemen nasionalis kebangsaan dan organisasi agama.

\section{KESIMPULAN}

Gerakan sosial yang muncul di era kolonialisme sebagai wujud dari resistensi rakyat Indonesia yang mulai mempunyai kesadaran atas hak-hak serta identitas yang bermartabat melalui serangkaian proses panjang. Gerakan sosial yang ditandai dengan kondisi yang penuh kegelisahan karena perasaan ketidakpuasan terhadap kehidupan sehari-hari akibat diskriminasi dan penindasan kolonialisme serta adanya keinginan dan harapan untuk dapat meraih tatanan kehidupan baru. Organisasi-organisasi massa yang muncul sebagai alternatif bagi penyampaian aspirasi dan perlawanan tampak mendapatkan antusiasme dari rakyat yang telah lama terkungkung. Sarekat Islam sebagai representasi umat Muslim baik santri dan abangan tampaknya mendapat tempat dalam hati masyarakat di berbagai kegiatan dan jumlah perwakilan yang semakin besar dengan tokoh kharismatiknya H.O.S Tjokroaminoto.

Indische Partij dan Insulinde menjadi gerakan sosial pertama yang melakukan advokasi secara langsung terhadap basis konstituennya serta tulisan-tulisan bernada kritik dan perlawanan dari koran terbitan mereka terhadap pemerintah kolonial yang berujung pada pengadilan dan pembuangan para pemimpinnya yang dikenal sebagai Tiga Serangkai dan Eugene Douwes Dekker sebagai tokoh sentral gerakan perlawanan.

Gerakan sosial dalam perspektif Smelser menyatakan adanya pernyataan spontan atau ketidakpuasan terhadap struktur sosial yang ada. Pemilihan pemimpin gerakan, pengorganisiran, konfrontasi dan pencapaian hasil telah menunjukkan hal yang sangat signifikan. Pergulatan dan dinamika gerakan sangat terlihat, situasi sosial, ekonomi politik yang banyak merugikan kalangan rakyat jelata semakin membuat popularitas organisasi massa semakin meningkat. Dengan slogan Indie Vor Indier, Indisce Partij mendeklarasikan sebagai partai politik bagi semua kelompok etnis, nasib orang Indo Eropa, orang Jawa dan bangsa lain yang tinggal di Nederland Indie atau Indonesia. IP mampu bekerjasama dengan baik dengan Sarikat Islam yang merupakan raksasa saat itu meski akhirnya kiprahnya meredup dan dilarang pemerintah kolonial akibat aksi-aksi politiknya membela rakyat Indonesia.

Munculnya paham komunis yang dibawa oleh segelintir orang Belanda mantan anggota aktivis Partai beraliran Marxis di Belanda yang bekerja di Indonesia dipimpin oleh Sneevliet. Tuntutannya jauh lebih radikal dengan menentang imperialisme dan kapitalisme menuju masyarakat komunis dan membawa arah gerakan sosial di Indonesia dengan berpisahnya Sarekat Islam Merah yang berhaluan Marxis 
menjadi lebih radikal sampai meletusnya pemberontakan pada 1926-1927 yang berhasil dipatahkan pemerintah kolonial Hindia Belanda tanpa kompromi. Itulah embrio-embrio perlawanan politik yang mewarnai konstelasi sejarah bangsa menuju lahirnya revolusi Indonesia yang akhirnya mampu memproklamasikan kemerdekaannya pada tanggal 17 Agustus 1945.

\section{DAFTAR PUSTAKA}

Himawan, Aris. 2011. Pendidikan Kolonial Studi Sekolah van Deventer di Mangkunegaran Surakarta. Jurnal Wanita Jawa, No. 3.

Gurr, Ted Robert. 1970. Why Men Rebbel. New Jersey: Princeton University Press.

Haryanto, 1997. Gerakan Sosial Politik. Jakarta: Badan Pendidikan dan Latihan, Departemen Dalam Negeri.
Mas'oed, Mohtar. 1997. Gerakan Sosial dan Politik. Jakarta: Badan Pendidikan dan Latihan, Departemen Dalam Negeri.

Ritzer, George. 1985. Sociology: A Multiple Paradigm Science, diterjemahkan oleh Alimandan. Jakarta: CV Rajawali.

Ritzer, George. 1979. Sociology: Experiencing a Changing Society. Massachusetts: Allyn and Bacon Inc.

McVey, Ruth. 2010. Kemunculan Komunisme Indonesia. Jakarta: Komunitas Bambu.

Tzabit, Ahmad. 2011. Sarekat Islam dan Gerakan Kiri di Semarang 1917-1920. Jurnal Sejarah dan Budaya, No. 2: 4.

Wiratha, I Made. 2006. Metode Penelitian Sosial Ekonomi. Yogyakarta: CV Andi.

Majalah Tempo. 2012. Tur Propaganda di Tanah Jawa. Edisi Agustus.

Majalah Tempo. 2012. Geger Polan Harjo di Basis Insulinde. Edisi Agustus.

Majalah Tempo. 2012. Tetap Membangkang Dalam Pembuangan. Edisi Agustus. 